Marwah: Jurnal Perempuan, Agama dan Jender (p-ISSN: 1412-6095 | e-ISSN: 2407-1587)

Vol. 17, No. 1, 2018, Hal. 01 - 19

\title{
GERAKAN SOSIAL KAUM PEREMPUAN MELAWAN EUPHORIA MEDIA MELALUI KOMUNITAS HIJABERS DI KOTA SURAKARTA
}

\author{
ALAN SIGIT FIBRIANTO \\ Universitas Sebelas Maret, Surakarta, Indonesia \\ alansigitfibrianto53@gmail.com \\ SYAMSUL BAKHRI \\ Universitas Sebelas Maret, Surakarta, Indonesia \\ sbakbri@,rocketmail.com
}

\begin{abstract}
The movement of young people who were once banned by the new order era, has now mushroomed and its existence is increasingly diverse, even today many new movements on behalf of his movement with the religious symbols. This research uses the concept of the theory of Social Identity, social communities, social movements, and Ecofeminism. This research uses qualitative research methods with the case study approach. The results of this research are divided into two categories, the first discussion, the community of hijabers as a social identity-forming, and secondly, the community of hijabers as the ideology of the social movements of women against the media euphoria. The second part answering the problems of women in terms of the existence of the hijab to resist euphoria media lately many phenomena highlighted the use of hijab in Indonesia that still shows the curve of the female body. Therefore, the presence of community hijabers as guards in the use of headscarves for muslim women in accordance with the Islamic Shari'a. In addition, as the arena friendship and sharing their experience and knowledge of Islam.
\end{abstract}

Keywords: Social Movements, Solo Hijabers Community, Social Identity, The Media Euphoria, Ecofeminism

\begin{abstract}
ABSTRAK
Pergerakan orang-orang muda yang pernah dilarang oleh era orde baru, kini telah menjamur dan eksistensinya semakin beragam, babkan saat ini banyak gerakan baru atas nama gerakannya dengan simbol-simbol agama. Penelitian ini menggunakan konsep teori Identitas Sosial, komunitas sosial, gerakan sosial, dan Ecofeminisme. Penelitian ini menggunakan metode penelitian kualitatif dengan pendekatan studi kasus. Hasil penelitian ini dibagi menjadi dua kategori, yaitu diskusi pertama, komunitas hijabers sebagai pembentukan identitas sosial, dan kedua, komunitas hijabers sebagai ideologi gerakan sosial perempuan terhadap euforia media. Bagian kedua menjawab masalah perempuan dalam hal keberadaan hijab untuk melawan euforia media akbir-akhir ini banyak fenomena yang menyoroti penggunaan jilbab di Indonesia yang masih memperlihatkan lekuk tubuh perempuan. Oleb karena itu, kehadiran hijabers masyarakat sebagai penjaga dalam penggunaan jilbab bagi wanita muslim sesuai dengan syariat Islam. Selain itu, sebagai arena pertemanan dan berbagi pengalaman dan pengetahuan mereka tentang Islam.
\end{abstract}

Kata Kunci: Gerakan Sosial, Komunitas Hijabers Solo, Identitas Sosial, Media Euforia, Ekofeminisme 


\section{A. PENDAHULUAN}

Gerakan pembaharuan untuk mengenakan jilbab muncul di Indonesia sejak tahun 1920-an dalam "Voices of Islam in Southeast Asia" (Fealy, 2006: 326). Enam puluh tahun kemudian, jilbab menjadi demikian populer ketika dianggap sebagai simbol kesalehan seseorang. Hal ini terjadi di Indonesia pada sekitar tahun 1980-an. Gerakan mengenakan jilbab yang dimulai oleh para remaja puteri ini pada awalnya dianggap sebagai fenomena politik oleh pemerintah orde baru. Bahkan jilbab sempat dilarang pada waktu itu karena dianggap sebagai bagian dari gerakan Islam dan dikhawatirkan menjadi simbol dari aliran politik tertentu. Pelarangan penggunaan jilbab pada tahun delapan puluhan dimulai dari kalangan peserta didik di sekolah-sekolah sampai perguruan tinggi, bahkan larangan juga diberlakukan untuk tenaga pendidik pada masa itu. Tuntutan dan perjuangan kaum perempuan terus dilakukan untuk terus mempertahankan hak dan kebebasan untuk menjalankan keyakinan dan agamanya. Dukungan juga mengalir dari berbagai pihak dan alhasil dari perjuangan itu muncullah SK 100/C/Kep/D/91 yang memperbolehkan penggunaan jilbab di lingkungan sekolah (Mustafa, 2000).

Kini, selama dua puluh tahun lebih setelah diterbitkannya peraturan yang memperbolehkan penggunaan jilbab di institusi pendidikan dan hingga saat ini, sudah tidak terhitung lagi berapa banyak para pelajar muslimah yang mengenakan jilbab sebagai bentuk kewajiban dalam ajaran agama Islam. Pemandangan lautan jilbab kini dapat kita jumpai khususnya di kalangan mahasiswi di Perguruan Tinggi. Hampir sebagian besar dari mereka mengenakan jilbab ketika beraktifitas di kampus. Seiring dengan fenomena tersebut, ternyata juga terdapat suatu komunitas kaitannya dengan penggunaan jilbab yaitu, disebut dengan komunitas hijabers. Berdasarkan observasi yang peneliti lakukan, ada sebuah komunitas hijabers di Solo, komunitas tersebut bernama "Solo Hijabers Community" atau Komunitas Solo Hijabers. Komunitas ini terdiri dari beberapa anggota diantaranya yaitu, remaja, mahasiswa dan juga ibu-ibu muda. Sebagian besar anggotanya adalah dari kalangan mahasiswa Universitas Sebelas Maret Surakarta (UNS) dan Universitas Muhammadiyah Surakarta (UMS). Solo hijabers adalah sebuah komunitas hijab bagi kaum perempuan muslim yang berpusat di Kota Solo dan terbuka untuk umum serta semua kalangan. Untuk ketuanya sendiripun masih terbilang sangat muda yaitu, seorang lulusan dari sebuah Universitas di Solo jenjang S1 pada Jurusan Sastra Inggris, Fakultas Sastra dan Seni Rupa (FSSR), Universitas Sebelas Maret 
Surakarta (UNS), angkatan 2008, beliau bernama Oki Sarah Faradina. Layaknya sebuah komunitas pada umumnya, Solo Hijabers memiliki beberapa agenda kegiatan atau program. Beberapa programnya yaitu, antara lain, mulai dari awal terbentuknya komunitas ini diadakan "Grand Launching", lalu beberapa kegiatan lainnya seperti, "Gathering Member", "Garage Sale”, "Butik Les", kegiatan pengajian rutin, "milad", dan lain sebagainya. Selain itu, juga ada banyak sekali toko-toko atau butik yang menawarkan pernak-pernik terkait produk jilbab bahkan dengan berbagai model dan cara penggunaannya. Toko atau butik tersebut sengaja ditempatkan di sekitar kampus dengan tujuan untuk kalangan mahasiswa yang menjadi sasaran utama dalam penjualannya. Namun, tidak semua toko atau butik produk hijab berhubungan dengan Komunitas Solo Hijabers, hanya ada beberapa toko atau butik yang terikat, baik dalam bentuk kontrak, kerja sama, maupun usaha anggota atau member dari Komunitas Solo Hijabers.

Penggunaan jilbab dengan berbagai model, bentuk dan cara menggunakannya telah menjadi trend masa kini, hal tersebut diperkuat dengan adanya komunitas hijabers yang digunakan sebagai wadah bagi kaum perempuan yang peduli akan penggunaan jilbab. Berdasarkan latar belakang diatas, muncul pertanyaan: 1) Mengapa Sekelompok Perempuan di Kota Surakarta membentuk Komunitas Solo Hijabers?; 2) Bagaimana bentuk gerakan sosial yang dilakukan oleh komunitas hijabers di Kota Surakarta, Jawa Tengah, Indonesia?

\section{B. TINJAUAN PUSTAKA}

Penelitian mengenai gerakan perempuan memang sudah pernah ada yang melakukan. Penelitian yang dilakukan oleh Sri Roviana (2014) mengenai "Gerakan Perempuan Nahdlatul Ulama dalam Transformasi Pendidikan Politik". Penelitian ini menghasilkan kesimpulan bahwa perempuan politisi dan penggerak di NU memiliki keterbatasan peran karena sebagian kyai masih cenderung menggunakan pola pikir dan sikap patriarkhi, dimana kepemimpinan perempuan hanya dapat diterima sebagai wacana, namun sulit diterima dalam politik riil. Pemikiran Khofifah Indar Parawansa, Masruchah, Musdah Mulia, Ermalena, Nursyahbani Katjasungkana, dapat diterima di kalangan aktivis berlatarbelakang NU dan diluar NU, namun justru dikalangan mainstreame NU, khususnya kyai dan nyai tradisional belum sepenuhnya menerima. Penelitian lain tentang gerakan perempuan juga dilakukan oleh Noneng Masitoh dan 
Fitriyani Yuliawati (2016) mengenai "Gerakan dan Representasi Politik Perempuan di Kota Tasikmalaya". Penelitian ini menghasilkan 3 kesimpulan, antara lain: 1) Organisasiorganisasi perempuan yang ada di Kota Tasikmalaya belum sepenuhnya memiliki wadah yang dapat mempersatukan semua golongan, sehingga gerakan masih dilakukan sendirisendiri oleh organisasi perempuan masing-masing; 2) Keterwakilan perempuan dalam lembaga politik formal cukup terwakili dengan munculnya tokoh-tokoh yang menjadi representasi perempuan dalam lembaga politik. Secara substantif, keberadaan mereka dalam lembaga-lembaga tersebut belum memberikan implikasi positif yang sangat signifikan; 3) Keberadaan GOW Kota Tasikmalaya sebagai salah satu wadah bersatunya organisasi-organisasi perempuan di Kota Tasikmalaya belum maksimal dalam mengkoordinir gerakan perempuan di Kota Tasikmalaya. Adapun penelitian lain yang membahas tentang hijab juga dilakukan oleh Ahmad Suhendra (2013) mengenai "Kontestasi Identitas Melalui Pergeseran Interpretasi Hijab dan Jilbab dalam AlQur'an". Penelitian ini menghasilkan kesimpulan bahwa telah terjadi pergeseran penggunaan penutup kepala perempuan yang di Indonesia disebut sebagai jilbab. Fenomena penggunaan jilbab bukan lagi dalam penghayatan religius, melainkan sebagai bagian dari trend modis pakaian. Kondisi ini berbeda dengan tujuan agama yang memberlakukan jilbab sebagai "perlindungan" terhadap perempuan dan menjadi identitas pembeda.

Penelitian ini menggunakan konsep teori Komunitas Sosial, Identitas Sosial, Gerakan Sosial, dan Ekofeminisme. Menurut Warren (dalam Tong, 1998: 360), modus berpikir patriarki yang hirarkis, dualistik, dan opresif telah merusak perempuan dan alam. Jelas karena perempuan telah "dinaturalisasi” (natural=alami[ah]) dan alam telah "difeminisasi”, maka sangatlah sulit untuk mengetahui kapan opresi yang satu berakhir dan yang lain mulai. Warren menekankan bahwa perempuan "dinaturalisasi" ketika mereka digambarkan melalui acuan terhadap binatang, misalnya, "sapi, serigala, ayam, ular, anjing betina, berang-berang, kelelawar, kucing, otak burung, otak kuda." Demikian pula alam "difeminisasi" ketika "ia" diperkosa, dikuasai, ditaklukkan, dikendalikan, dipenetrasi, dikalahkan, dan ditambang oleh laki-laki, atau ketika "ia" dihormati atau bahkan disembah sebagai "ibu” yang paling mulia dari segala ibu. Jika laki-laki adalah tuan dari alam, jika laki-laki telah diberi kekuasaan atas alam, maka ia mempunyai kendali tidak saja atas alam, tetapi juga atas perempuan. Apapun yang dapat dilakukan laki-laki terhadap alam dapat dilakukan kepada perempuan. Dari pengertian tersebut, maka 
secara singkat ekofeminisme dapat diartikan sebagai paham mengenai wujud ketertindasan perempuan karena budaya yang diawali dengan konsep alam. Pada era sekarang dengan kehadiran teknologi sebagai sebuah penciptaan baru atas budaya baru yang bahkan kehadirannya didominasi oleh kaum laki-laki. Bahkan keberadaan teknologi beberapa diantaranya sengaja dihadirkan sebagai sebuah wujud opresi baru terhadap kaum perempuan. Dalam ekofeminisme teknologi bukan untuk mendukung eksistensi perempuan, melainkan sebagai sebuah wujud baru yang merugikan bagi perempuan. Contoh, fotografer (identik dengan kaum laki-laki sebagai pengguna teknologi), menyebabkan objek perempuan yang menjadi kasus pornografi, bahkan pornoaksi di mana perempuan sebagai pemuas hawa nafsu laki-laki yang dilakukan dengan memanfatkan teknologi. Hal itu sebagai bukti bahwa sebenarnya budaya dan konsep alam bisa menjadi sebuah wujud opresi terhadap kaum perempuan.

Komunitas merupakan sebuah kelompok sosial dari beberapa organisme yang berbagi lingkungan, umumnya memiliki ketertarikan dan habitat yang sama. Dalam komunitas manusia, individu-individu di dalamnya dapat memiliki maksud, kepercayaan, sumber daya, preferensi, kebutuhan, resiko dan sejumlah kondisi lain yang serupa. Komunitas berasal dari bahasa latin communitas yang berarti "kesamaan", kemudian dapat diturunkan dari communis yang berarti "sama, publik, dibagi oleh semua atau banyak" (Wenger, dkk, 2002: 4).

Komunitas terbentuk biasanya untuk menunjukkan identitas suatu kelompok tertentu. Hogg dan Abram (1990) menjelaskan social identity sebagai rasa keterkaitan, peduli, bangga dapat berasal dari pengetahuan seseorang dalam berbagai kategori keanggotaan sosial dengan anggota yang lain, bahkan tanpa perlu memiliki hubungan personal yang dekat, mengetahui atau memiliki berbagai minat.

Menurut William James (dalam Walgito, 2002), identitas sosial lebih diartikan sebagai diri pribadi dalam interaksi sosial, di mana diri adalah segala sesuatu yang dapat dikatakan orang tentang dirinya sendiri, bukan hanya tentang tubuh dan keadaan fisiknya sendiri saja, melainkan juga tentang yang lain-lain miliknya atau yang berkaitan dengannya. Terdapat empat dimensi dalam mengkonseptualisasikan identitas sosial, Menurut Jackson and Smith (dalam Baron and Donn, 1991), antara lain yaitu, persepsi dalam konteks antar kelompok, daya tarik in-group, keyakinan saling terkait, dan depersonalisasi. Keempat dimensi tersebut, cenderung muncul ketika individu berada di tengah-tengah kelompok. 
Komunitas hijabers merupakan komunitas yang terdiri dari beberapa kelompok dan individu pengguna jilbab. Hijab diartikan sebagai suatu tindakan dari seorang wanita yang dalam agama Islam telah menjalankan salah satu syariat Islam yaitu dengan berhijab. Berhijab diartikan sebagai tindakan menutup aurat bagi kaum perempuan yang diwajibkan hukumnya di dalam agama Islam. Hijab dapat dilakukan dengan menggunakan simbol penutup aurat bagi kaum perempuan yaitu, dengan menggunakan jilbab dan/atau kerudung. Selain manfaat atau tujuan secara agamis, ternyata komunitas hijabers juga bertujuan sebagai pembentukkan sebuah identitas tertentu di dalamnya.

Secara umum Gerakan Sosial memiliki definisi yang luas karena beragamnya ruang lingkup yang dimilikinya. Giddens dalam Suharko (2006) menyatakan bahwa gerakan sosial adalah suatu upaya kolektif untuk mengejar suatu kepentingan bersama, atau gerakan mencapai tujuan bersama melalui tindakan kolektif (collective action) di luar lingkup lembaga-lembaga yang mapan. Pengertian yang nyaris persis diutarakan oleh Tarrow dalam Suharko (2006) yang menempatkan Gerakan Sosial sebagai politik perlawanan yang terjadi ketika rakyat biasa -yang bergabung dengan para kelompok masyarakat yang lebih berpengaruh- menggalang kekuatan untuk melawan para elit, pemegang otoritas, dan pihak-pihak lawan lainnya. Ketika perlawanan ini didukung oleh jaringan sosial yang kuat, dan digabungkan oleh resonansi kultural dan simbol-simbol aksi, maka politik perlawanan mengarah ke interaksi yang berkelanjutan dengan pihakpihak lawan, dan hasilnya adalah gerakan sosial.

Ada beberapa ciri dari gerakan sosial baru, diantaranya yaitu, kumpulan kekuatan sosial baru ini bergerak menentang konsepsi otonomi dan kebebasan manusia, menentang konsepsi kedaulatan tubuh, kedaulatan moral, etis dan konsepsi religius ihwal kesejahteraan dalam masyarakat. Perlu disadari bahwa gerakan sosial baru bukanlah demi anarki, ia menyerukan sebuah kondisi yang adil dan bermartabat bagi konsepsi kelahiran, kedewasaan, dan reproduksi makhluk manusia yang kreatif dan berseiring dengan alam. kemudian, secara radikal gerakan sosial baru mengubah paradigma Marxis yang menjelaskan konflik dan kontradiksi dalam istilah 'kelas' dan konflik kelas. Nalar akademisi kiri menyajikan penafsiran diri yang menyingkirkan klaimklaim dan kontestasi kelompok-kelompok yang muncul dari isu-isu terkait dengan gender, ekologi, ras, etnis, dll, dari sistem penjelasan Marxis tentang gerakan dan perubahan dalam masyarakat. Marxisme memandang semua bentuk perjuangan sebagai perjuangan kelas dan semua bentuk pengelompokkan manusia sebagai perkelompokkan 
kelas. Banyak perjuangan kontemporer seperti anti-rasisme, perlucutan senjata, gerakan feminis dan environmentalism, bukanlah perjuangan kelas dan juga bukan cerminan sebuah gerakan kelas. Pengelompokkan mereka adalah lintas kelas. Dalam konteks sosial kontemporer, Marxisme terbukti menjadi model penjelasan yang tidak cocok. Dengan kata lain terjadi sebuah keruntuhan umum 'paradigma kelas' sebagai 'general theory' dalam ilmu-ilmu sosial. Medan konflik sosial dalam mode Marxis biasanya dilihat sebagai lokasi struktur kelas masyarakat. Dalam perkembangannya sekarang, konflik sosial melebihi dan meluber keluar dari ruang-ruang sosial berdasarkan kelas, ia meluas melintasi kotak-kotak pengkhususan masyarakat atau sistem politik. Gerakan sosial baru adalah gerakan transnasional. Gerakan ini menyuarakan, mengarah dan berjuang bagi isu-isu kemanusiaan dan isu-isu yang berhubungan dengan kondisi mendasar keberadaan manusia serta mungkin bagi keberadaan yang layak di masa depan. Karenanya sejumlah tujuan dan targetnya berlokasi di wilayah lintas masyarakat kemanusiaan global. Gerakan sosial baru mencari jawaban atas pertanyaan yang terkait dengan perdamaian, ekologi, lingkungan, dan hak-hak asasi manusia. Komitmen mereka melintasi paradigm kelas dan melampaui ketidakmampuan penjelasan materialistik Marxis untuk menjawab gerakan baru kontemporer ini. Karenanya Gerakan Sosial Baru didefinisikan oleh tampilan mereka yang non-kelas serta pusat perhatian dan penekanan yang non-materialistik (Singh, 2010).

\section{METODE PENELITIAN}

Dalam penelitian ini digunakan metode atau jenis penelitian kualitatif. Penelitian kualitatif merupakan suatu proses kegiatan yang mengungkapkan secara logis, sistematis dan empiris terhadap fenomena-fenomena sosial yang terjadi di sekitar untuk direkonstruksi guna mengungkapkan kebenaran yang bermanfaat bagi kehidupan masyarakat dan ilmu pengetahuan. Kebenaran yang dimaksud adalah keteraturan yang menciptakan keamanan, ketertiban, keseimbangan dan kesejahteraan masyarakat (Iskandar, 2009). Menurut Miles dan Huberman (Poerwandari, 2007) penelitian kualitatif kurang lebihnya dapat dianalogikan dengan proses penyelidikan, tidak banyak berbeda dengan kerja detektif yang harus mendapat gambaran tentang fenomena tertentu yang diselidiki. Kirk dan Miller (Moleong, 2000) mengartikan penelitian kualitatif sebagai sebuah tradisi tertentu dalam ilmu pengetahuan sosial yang secara fundamental bergantung pengamatan pada manusia dalam kawasannya sendiri dan berhubungan 
dengan orang-orang tersebut. Bogdan dan Tylor (dalam Moleong, 2007: 4) mengemukakan metode penelitian kualitatif sebagai prosedur penelitian yang menghasilkan data deskripsi yang berupa kata-kata tertulis atau lisan dari orang-orang dan perilaku yang diamati.

Penelitian ini menggunakan metode penelitian kualitatif dengan metode studi kasus. Studi kasus menurut Yin (Salim, 2006:118) digunakan untuk menjawab pertanyaan penelitian berupa "bagaimana" dan "mengapa" terhadap seperangkat peristiwa masa kini. Studi kasus sendiri dapat diartikan sebagai sebuah metode atau strategi penelitian pada kasus tertentu. Studi kasus dipahami sebagai pendekatan untuk mempelajari, menerangkan atau menginterpretasikan suatu kasus dalam konteks yang alamiah tanpa ada intervensi dari pihak luar (Salim, 2006: 118). Studi kasus memungkinkan peneliti untuk mempertahankan karakteristik holistik dan bermakna dari peristiwa-peristiwa kehidupan nyata seperti siklus kehidupan seseorang, proses-proses organisasional dan manajerial, perubahan lingkungan sosial, hubungan-hubungan internasional, dan kematangan industri-industri (Yin, 2015: 4). Penelitian studi kasus adalah suatu penelitian yang dilakukan secara intensif, terinci, dan mendalam terhadap suatu organisasi, lembaga, atau gejala tertentu (Arikunto, 2006: 142). Lokasi penelitian ini dilakukan di Kota Surakarta, Jawa Tengah, Indonesia. Adapun alasan pemilihan lokasi dikarenakan kemunculan Komunitas Hijabers Surakarta kian menunjukkan pergerakan yang dinamis serta merangkul kalangan perempuan baik tua maupun muda untuk bersama-sama menjalin silaturahim dan menjadi wadah dalam berbenah diri dalam hal pengguanaan hijab yang merupakan landasan terbentuknya komunitas ini, selain itu dalam Komunitas Solo Hijabers ini juga mengedepankan cara berhijab yang benar sesuai tuntunan agama dan bukan hanya sekadar fashion belaka yang saat ini bahkan kehadiran pengguna jilbab yang dirasa meresahkan kaum perempuan karena tidak sesuai dengan tuntunan agama Islam (yang baik dan benar/ yang menutup aurat).

Informan penelitian ini adalah pendiri komunitas hijabers surakarta, Mantan ketua komunitas hijabers surakarta, ketua komunitas hijabers surakarta, dan anggota komunitas hijabers surakarta. Teknik pengumpulan data yang digunakan adalah studi kepustakaan, observasi, wawancara dan dokumentasi. Validitas data yang digunakan adalah teknik triangulasiteknik pemeriksaan data. Teknik analisis data mencakup empat hal yaitu pengumpulan data, reduksi data, penyajian data, dan penarikan kesimpulan atau verifikasi. 


\section{HASIL DAN PEMBAHASAN}

\section{Komunitas Hijabers sebagai Pembentuk Identitas Sosial}

Ada banyak sekali komunitas sosial yang tersebar luas di masyarakat. Terbentuknya komunuitas-komunitas tersebut dilatarbelakangi oleh berbagai hal. Ada komunitas yang terbentuk karena hobi, ada pula komunitas yang terbentuk dikarenakan keinginan menjalin silaturahmi antar sesama, dan lain sebagainya. Masing-masing komunitas seolah-olah menunjukkan karakter tersendiri ataupun kelebihan-kelebihan yang dimiliki. Hal tersebut dilakukan untuk memperoleh suatu eksistensi terhadap masyarakat luas, agar dapat dikenal dan diketahui oleh khalayak umum. Masing-masing komunitas berlomba-lomba untuk menunjukkan eksistensinya dengan mengadakan berbagai kegiatan atau membentuk program-program di tengahtengah masyarakat. Berbagai kegiatan tersebut yang nantinya akan membentuk yang namanya identitas sosial, dimana masing-masing komunitas memiliki karakter dan tujuan yang berbeda-beda.

Komunitas Solo Hijabers adalah salah satu dari sekian banyak komunitas di Kota Solo. Tidak jauh berbeda dengan komunitas-komunitas pada umumnya, Komunitas Solo Hijabers ini juga memiliki karakter serta tujuan tertentu untuk menunjukkan atau membentuk suatu identitas sosial di dalamnya. Identitas sosial inilah yang nantinya diharapkan akan dapat diterima oleh masyarakat umum dan diakui keberadaannya. Komunitas Solo Hijabers ini diketuai oleh seorang perempuan bernama Oki Sarah Faradina, yang biasa dipanggil dengan nama panggilan Oki. Ia merupakan lulusan dari salah satu Perguruan Tinggi di Kota Solo yaitu, Universitas Sebelas Maret Surakarta, dengan mengambil jurusan Sastra Inggris, Fakultas Sastra dan Seni Rupa, angkatan 2008. Oki lahir di Kabupaten Blora pada tanggal 16 Maret 1990. Komunitas Solo Hijabers ini telah terbentuk hampir enam tahun lamanya, tepatnya pada tanggal 09 September 2011 hingga sekarang. Oki menjelaskan bahwasanya pada awal mula terbentuknya komunitas ini dikarenakan dulu pada tahun 2011 sedang trend yang namanya hijabers community di Jakarta. Untuk Komunitas Hijabers di Jakarta sendiri telah berdiri sejak tahun 2010. Lalu, bermula dari temanteman bermain dan berkumpul bersama, ada satu-dua orang yang memiliki unekunek dan pada waktu itu muncul pertanyaan dari salah seorang teman, "Kenapa kita gak bikin sendiri aja komunitas hijabers, tapi di Solo?”, dan dari pertanyaan itulah kemudian muncul gagasan atau sebuah ide untuk membuat komunitas hijabers di 
Solo, yang akhirnya terbentuklah sebuah komunitas yang bernama "Solo Hijabers". Oki menjelaskan bahwa ada beberapa atau sedikit perbedaan antara Komunitas Solo Hijabers dengan Komunitas Hijabers yang ada di Jakarta. Perbedaan tersebut yaitu, bila Komunitas Hijabers di Jakarta lebih berkiblat ke fashion, akan tetapi bila di Solo Hijabers, membentuk komunitas ini hanya untuk sekadar ajang silaturahmi antar sesama muslimah di Solo. Selain itu, komunitas Solo Hijabers juga digunakan sebagai wadah atau tempat untuk belajar bersama-sama tentang berjilbab serta menambah wawasan dengan belajar bersama terkait ajaran-ajaran dalam agama Islam, dan untuk menambah saudara.

Tujuan dibentuknya Komunitas Solo Hijabers adalah sebagai suatu wadah bagi kaum perempuan untuk berkumpul bersama, belajar berhijab bersama, menambah wawasan bersama-sama tentang ilmu keagamaan, menumbuhkan rasa persatuan dengan adanya jalinan silaturahmi antar sesama muslimah dan menambah saudara. Dari tahun ke tahun, Komunitas Solo Hijabers terus mengalami perkembangan. Dari tahun 2011 yang semula jumlah anggotanya hanya sedikit dan sampai akhir tahun 2011 anggotanya hanya kurang dari 100 orang, dan sampai akhir tahun 2013, jumlah anggota terus mengalami penambahan hingga kurang lebih sebanyak 400 anggota di dalam Komunitas Solo Hijabers ini. Pada mulanya, Komunitas Solo Hijabers hanya terdiri dari 30 orang anggota pengajian dan sampai sekarang jumlah anggotanya telah lebih dari 400 orang. Pencetus atau penggagas di dalam berdirinya Komunitas Solo Hijabers adalah seorang perempuan yang bernama Vivi dan menjadi ketua pertama kali di Komunitas Solo Hijabers tersebut. Vivi bersama teman-temannya yaitu, Maus, Rice, dan Rosti, berawal dari berkumpul bersama dengan teman-teman lama, akhirnya memiliki keinginan untuk membentuk komunitas hijabers di Kota Solo. Vivi dan teman-temannya itu bermula hanya terjalin melalui media sosial dan tergabung dalam pertemanan di online shop. Lalu, mereka pada akhirnya sering bertemu dan menjadi teman akrab serta pada suatu hari tercetus ide untuk membentuk suatu komunitas hijabers.

Tanggapan masyarakat umum positif terhadap keberadaan Komunitas Solo Hijabers ini, karena di dalam komunitas ini juga kerap kali membuat event atau program yang langsung berhubungan dengan masyarakat secara langsung, seperti halnya kegiatan amal, bakti sosial, "garage sale" (menjual barang-barang muslim bekas) yang hasilnya disumbangkan ke panti-panti, baik itu panti asuhan maupun 
panti jompo. Akan tetapi, ada pula segelintir orang di masyarakat yang kontra dengan komunitas ini, misalnya dulu pernah diundang di dalam salah satu acara televisi dan ada sesi komunikasi interaktif via telefon dengan masyarakat yang sedang menyaksikan acara tersebut untuk sekadar bertanya, memberi komentar atau tanggapan, dan lain sebagainya. Namun, ada dari salah seorang dari pihak penelfon yang berkomentar atau beranggapan bahwa Komunitas Solo Hijabers adalah wadah untuk sekadar fashion saja, untuk hura-hura, dan lain sebagainya. Selain itu, ada pula dari orang lain ataupun mahasiswa lainnya yang juga menganggap demikian. Padahal, di dalam Komunitas Solo Hijabers ini, menurut Oki selaku Ketua komunitas tersebut, menganggap bahwa terbentuknya komunitas ini adalah sebagai wadah untuk belajar bersama dan mencoba untuk belajar berhijab dan berbagi wawasan atau keilmuan di bidang agama Islam, dan sama sekali tidak ada hura-huranya. Oki juga menambahkan, bahwa setiap orang belajar untuk menjadi baik pasti membutuhkan tahapan dan proses untuk belajar, tidak ada yang langsung bisa sempurna menjadi baik. Sama halnya di Komunitas Solo Hijabers ini, dimana seluruh anggotanya adalah terdiri dari individu-individu yang ingin belajar bersama untuk menutup aurat atau berhijab dan belajar untuk menjalankan syariat-syariat di dalam ajaran agama Islam dan tidak ada niat sedikitpun untuk seperti apa yang orang-orang anggap negatif terhadap komunitas ini.

Di dalam Komunitas Solo Hijabers ini juga terdapat berbagai kegiatan, diantaranya di awal pembentukkan komunitas ini sempat diadakan "Grand Launching” yang bertempat di Solo Grand Mall dengan mengadakan kegiatan atau program dengan tema "All day long with Solo Hijabers" sebagai bentuk kegiatan pembuka atau pengenalan pertama kali Komunitas Solo Hijabers kepada masyarakat umum. Selain itu, di Komunitas Solo Hijabers juga mengadakan program "Gathering Member” untuk semua member Solo Hijabers. Kemudian, ada pula program "Garage Sale" yang diadakan untuk setiap tahunnya. Jadi, kegiatan garage sale ini yaitu, semacam mengumpulkan barang-barang bekas layak pakai dan layak jual, yang kemudian dijual dan hasil penjualan nantinya disumbangkan ke panti-panti atau kepada pribadi atau orang-orang yang membutuhkan. Lalu, untuk program yang lain, seperti “Butik Les" yaitu, kegiatan mengenai tutorial atau tata cara penggunaan jilbab, jadi saling sharing cara menggunakan jilbab. Ada pula kegiatan pengajian rutin yang diadakan setiap satu bulan sekali yang dilaksanakan pada minggu ke empat di setiap 
bulannya. Ada juga program "milad" atau program untuk mengenang hari jadi Komunitas Solo Hijabers yang diadakan setiap satu tahun sekali.

Oki menegaskan bahwasanya Solo Hijabers adalah Komunitas non-profit, walaupun ada beberapa anggota di dalam Komunitas Solo Hijabers yang berkecimpung di dunia online shop. Akan tetapi, tidak ada kegiatan jual-beli barang yang mengatas namakan Komunitas Solo Hijabers, jadi komunitas ini adalah komunitas non-profit. Walaupun kebanyakan member dan komite-komite yang lama memang kebetulan memiliki online shop masing-masing. Jadi, di dalam Komunitas Solo Hijabers ini, tanpa disengaja mungkin juga bisa seperti halnya sebagai wadah cari rejeki sama-sama. Jadi, siapa yang memiliki online shop, maka ia juga dapat mempromosikan produk dagangannya di Komunitas Solo Hijabers, ke membermember yang lain, dan Alhamdulillah hal tersebut juga bisa jalan sampai sekarang. Jadi, kegiatan jual-beli atau online shop tidak mengatas namakan Komunitas, akan tetapi mengatas namakan pribadi masing-masing yang memiliki usaha-usaha tersendiri, baik itu online shop maupun yang lainnya.

Untuk sumber dana di Komunitas Solo Hijabers itu sendiri mampu untuk mengadakan segala kegiatan atau program-program yaitu, berasal dari sponsorsponsor, dan semisal terpaksa masih ada kekurangan, maka hal itu menjadi tanggung jawab anggota untuk bersama-sama turut membantu mensukseskan setiap acara ataupun kegiatan di Komunitas Solo Hijabers. Jadi, bila ada kekurangan dana untuk setiap kegiatan, maka ditotal semua kekurangannya, lalu dipukul rata untuk semua anggota Komunitas Solo Hijabers untuk turut bersama-sama membantu dari kekurangan yang dibutuhkan.

Untuk struktur kepengurusan di dalam Komunitas Solo Hijabers tidak memiliki bidang-bidang tertentu. Jadi, untuk kepengurusan disesuaikan dengan bakat dan kemampuan dari masing-masing anggota atau komite-komite yang ada. Hal itu dapat bermanfaat ketika ada suatu kegiatan-kegiatan di dalam komunitas. Semisal, ketika ada anggota yang memiliki bakat foto, maka ia dijadikan sie dokumentasi di setiap kegiatan, dan yang rajin dijadikan sekretaris, dan untuk pemilihan ketua dari kepengurusan yang pertama kepada kepengurusan yang sekarang atau yang selanjutnya dilakukan pemilihan dengan secara musyawarah sebagai suatu bentuk regenerasi untuk menjadi ketua selanjutnya dan selanjutnya. Jadi, untuk kepengurusan, menurut Oki selaku ketua tidak harus saklek, untuk struktur 
kepengurusan terbentuk mengalir ketika ada kegiatan dan selalu dilakukan secara bersama-sama. Di dalam Komunitas Solo Hijabers tidak ada bidang-bidang yang harus terbentuk, namun hanya sekadar pembentukkan kepanitiaan di dalam setiap program atau kegiatan di dalam Komunitas Solo Hijabers.

Untuk kegiatan-kegiatan Komunitas Solo Hijabers itu sendiri baru sebatas di area Kota Solo. Jadi, untuk pelaksanaan kegiatan masih di lingkup Kota Solo. Namun, Komunitas Solo Hijabers juga sering diundang dalam kegiatan komunitas lain, seperti undangan untuk menghadiri Komunitas Hijabers Yogyakarta, dan juga Komunitas Hijabers Semarang. Komunitas Solo Hijabers sering juga diundang untuk kegiatan pengajian di lingkup Karisidenan Kota Surakarta, seperti undangan pengajian di Karanganyar, pengajian di Sukoharjo, dan lain sebagainya.

Untuk sistem perekrutan di Komunitas Solo Hijabers ini lebih kepada sistem dengan istilah "gethok tular", jadi dari orang ke orang, dan tidak ada sistem perekrutan khusus yang harus dilakukan, hanya saja ketika ada anggota yang mendaftar, untuk selanjutnya akan diberikan kartu sebagai tanda keanggotaan atau member. Kartu member ini dapat digunakan juga untuk kartu belanja dan mendapatkan diskon atau sewaktu ada promo akan mendapatkan potongan dengan menunjukkan kartu member tersebut. Akan tetapi, kelebihan kartu ini hanya dapat digunakan pada toko ataupun butik yang telah memiliki ikatan kerja sama antara Komunitas Solo Hijabers dengan pihak terkait. Untuk mendapatkan kartu member keanggotaan ini, maka setiap calon anggota diharuskan mengisi sebuah formulir terlebih dahulu dan membayar untuk uang kas anggota sebesar Rp 25.000,-. Setelah lengkap semua persyaratan, maka calon anggota baru akan mendapatkan kartu member dan setelah itu, maka dapat dianggap sebagai anggota atau member di Komunitas Solo Hijabers. Selain itu, setiap anggota atau member juga akan mendapatkan pin dan juga stiker. Keuntungan menjadi member Komunitas Solo Hijabers ini juga bisa mendapatkan diskon di online shop - online shop yang berada di dalam Komunitas Solo Hijabers itu sendiri. Untuk keanggotaan di Komunitas Solo Hijabers tidak ada pengotakkan harus mahasiswa atau remaja, akan tetapi siapa pun yang ingin ikut dan bergabung di dalam komunitas ini, maka akan diterima, baik itu anak-anak, remaja umum, mahasiswi, ibu-ibu, dan lain sebagainya. Oki juga menjelaskan bahwa tidak harus jadi member pun juga tidak apa-apa. Jadi, semisal 
hanya ingin ikut acara pengajian atau kegiatan-kegiatan lainnya, maka bisa langsung datang dan bergabung tanpa harus menjadi anggota atau member.

Untuk tempat kesekretariatan resmi bagi Komunitas Solo Hijabers itu sendiri tidak ada tempat resmi untuk setiap anggotanya berkumpul. Akan tetapi, untuk setiap kegiatan pengajian rutin diadakan di daerah Lodji Wetan, tepatnya di Gang sebelum Luwes, di daerah Sangkrah, dan pengajian diadakan di kediaman Vivi selaku mantan ketua di Komunitas Solo Hijabers pertama kali. Untuk tempat berkumpul pun juga terkesan fleksibel, dan kebanyakan berkumpul di tempat-tempat umum, seperti di rumah makan, dan lain sebagainya. Untuk anggota mahasiswa di Komunitas Solo Hijabers ini kebanyakan adalah mahasiswa Universitas Sebelas Maret dan Universitas Muhammadiyah Surakarta. Selain itu, untuk keanggotaan juga ada beberapa ibu-ibu muda dan remaja-remaja putri, baik remaja putri SMP, remaja putri SMA, maupun remaja putri SMK.

Di dalam Komunitas Solo Hijabers ini juga tidak ada pengelompokkan pemakaian jilbab harus seperti ini, harus seperti itu. jadi, bagi semua anggota dibebaskan untuk pemakaian jilbab, tidak ada keharusan model penggunaan jilbab harus seperti apa. Namun, di dalam kegiatan pengajian juga terkadang terdapat bahan tambahan materi untuk "Hijab Tutorial”, jadi di dalamnya diajarkan mengenai tata cara penggunaan jilbab. Setiap anggota Komunitas Solo Hijabers juga dapat saling berbagi wawasan mengenai cara menggunakan jilbab antara anggota yang satu dengan anggota yang lainnya tanpa harus melalui kegiatan saja, akan tetapi apa bila ada anggota yang tertarik dengan model jilbab anggota yang lain, maka dapat langsung bertanya dan belajar menggunakannya. Selain itu, Komunitas Solo Hijabers juga sering diundang di acara-acara lain di luar Komunitas Solo Hijabers untuk mengisi materi tentang "Hijab Tutorial". Jadi, intinya di Komunitas Solo Hijabers ini digunakan sebagai wadah bagi kaum muslimah untuk belajar bersama dan berbagi segala hal terkait tentang berhijab, maupun segala hal yang berkaitan tentang wawasan dan pengetahuan mengenai ajaran-ajaran dalam agama Islam, dan untuk keeksisan itu sendiri untuk Komunitas Solo Hijabers sudah banyak dikenal oleh masyarakat umum. Hal ini yang juga akan membentuk identitas sosial tersendiri bagi Komunitas Solo Hijabers. 


\section{Komunitas Hijabers sebagai Ideologi Gerakan Sosial Kaum Perempuan Melawan Euphoria Media}

Gerakan sosial lahir dari situasi yang dihadapi masyarakat karena adanya ketidakadilan dan sikap sewenang-wenang terhadap rakyat. Dengan kata lain gerakan sosial lahir sebagai reaksi terhadap sesuatu yang tidak diinginkannya atau menginginkan perubahan kebijakan karena dinilai tidak adil. Biasanya gerakan sosial seperti itu mengambil bentuk dalam aksi protes atau unjuk rasa di tempat kejadian atau di depan gedung dewan perwakilan rakyat atau gedung pemerintah. Setelah Mei 1998, gerakan sosial semakin marak dan ketidakadilan atau ketidakpuasan yang muncul jauh sebelum 1998 dibongkar untuk dicari penyelesaiannya. Situasi itu menunjukkan bahwa di mana sistem politik semakin terbuka dan demokratis maka peluang lahirnya gerakan sosial sangat terbuka. Menurut Giddens (1993), gerakan sosial adalah suatu upaya kolektif untuk mengejar suatu kepentingan bersama, atau gerakan mencapai tujuan bersama melalui tindakan kolektif (collective action) (Suharko, 2006). Gerakan pembaharuan untuk mengenakan jilbab muncul di Indonesia sejak tahun 1920-an dalam "Voices of Islam in Southeast Asia" (Fealy, 2006: 326). Enam puluh tahun kemudian, jilbab menjadi demikian populer ketika dianggap sebagai simbol kesalehan seseorang. Hal ini terjadi di Indonesia pada sekitar tahun 1980-an. Gerakan mengenakan jilbab pertama kali dimulai oleh para remaja putri pada waktu itu. Kemudian, setelah diturunkannya SK 100/C/Kep/D/91 yang memperbolehkan penggunaan jilbab di lingkungan sekolah, maka banyak remaja putri yang mengenakan jilbab di ranah pendidikan, baik di sekolah, maupun di Perguruan Tinggi (Mustafa, 2000).

Sekarang setelah kaum perempuan mendapatkan hak dan kebebasan untuk menjalankan keyakinan dan agamanya serta dalam penggunaan jilbab, maka untuk menjalankan syariat Islam dapat dilaksanakan dengan tenang dan hikmat. Tak hanya itu, banyak saat ini bermunculan ormas-ormas yang mengatas namakan agama Islam, banyak LSM-LSM yang terbentuk, banyak organisasi-organisasi berbasis Islam di sektor pendidikan, Rohis di SMA, di Universitas Sebelas Maret Surakarta misalnya, seperti Unit Kegiatan Mahasiswa (UKM) SKI, JN UKMI, ada pula organisasi eksternal seperti KAMMI (Kesatuan Aksi Mahasiswa Muslim Indonesia), HMI (Himpunan Mahasiswa Islam), PMII (Persatuan Mahasiswa Islam Indonesia), GEMMA (Gerakan Mahasiswa Menghafal Al-Qur'an), dan bahkan sampai yang 
radikal sekalipun seperti "Gerakan Pembebasan" yang menentang akan kebijakan pemerintah Negara, mengkritisi segala sistem dan menyalahkan konsep Negara, serta kontra akan ideologi bangsa Indonesia, dengan sebuah cita-cita yang diusungnya yaitu untuk mendirikan Negera khilafah. Itulah sekelumit gerakan-gerakan sosial masyarakat di lingkup pendidikan di Indonesia.

Terkait Komunitas yang sekarang juga telah marak dan bahkan anggotanya tersebar luas di masyarakat, di mana tempat kita tinggal. Salah satunya yaitu, Komunitas Solo Hijabers, dan jika dikaitkan dengan teori gerakan sosial dan menurut Giddens, maka di dalam Komunitas Solo Hijabers adalah merupakan suatu upaya kolektif dari setiap individu-individu di dalam kelompok sosial yang membentuk suatu komunitas yang juga memiliki suatu tujuan bersama. Dari Komunitas Solo Hijabers memiliki tujuan untuk menjalin silaturahmi antar sesama umat muslimah, yang terbentuk berawal dari keinginan sekelompok orang yang ingin membuat perubahan serta mengaktualisasikan diri melalui suatu kelompok sosial, yang kemudian sekarang disebut dengan Komunitas Solo Hijabers. Adanya suatu pergerakkan tidak lepas dengan adanya sistem pengkaderan, dimana setiap organisasi gerakan memerlukan anggota untuk bisa tetap hidup dan berkembang luas di masyarakat, hal ini juga akan berpengaruh pada pencapaian tujuan yang telah ditentukan di dalam organisasi. Selain sistem pengkaderan, hal yang lainnya yang patut diperhatikan yaitu, tentang keberlangsungan organisasi, baik itu kader, maupun kegiatan serta fasilitas. Untuk mencapai tujuan, maka diperlukan persamaan pandangan dan pola pikir, dalam hal ini berarti penekanan ideologi bagi setiap anggota. Karena berbeda pandangan dan ideologi, maka hal ini akan menghambat setiap organisasi ataupun kelompok dalam menggapai tujuannya, karena tidak ada keserasian antar anggota, sehingga menyebabkan suatu gerakan dapat melemah dan bahkan tidak akan bertahan lama.

Komunitas Solo Hijabers dapat dikatakan suatu gerakan sosial, hal ini dikarenakan di dalam komunitas ini terdapat individu-individu sebagai anggota yang terkoordinir dan membentuk suatu tindakan kolektif, dimana tindakan kolektif di dalamnya memiliki suatu kepentingan bersama. Contoh: dengan mengadakan segala aktivitas dan program kegiatan, yang dilakukan oleh setiap anggotanya secara sadar dan tanpa paksaan, maka hal tersebut sudah jelas bahwasanya Komunitas Solo Hijabers memiliki kepentingan dan tujuan di balik itu semua, dan pelaksanaannya 
secara kolektif yaitu, adanya kerjasama atau upaya kolektif (dengan sadar) di dalamnya, melakukan segala aktivitas yang sama, dengan bergerak bersama, memiliki pandangan yang sama, serta memiliki tujuan yang sama pula. Itulah yang menjadikan Komunitas Solo Hijabers sebagai sebuah gerakan sosial baru di tengah-tengah masyarakat Indonesia saat ini.

Perlawanan terhadap euphoria fashion hijab yang tidak sesuai dengan tuntunan agama Islam menjadi salah satu tujuan utama komunitas hijabers Solo. Fenomena banyaknya pemakai hijab tapi tetap menunjukan lekuk tubuhnya yang disebut dengan jilboob merupakan sebuah wujud euphoria media yang masih menjadikan tubuh wanita sebagai objek. Gaya hijab yang menunjukan lekuk tubuhnya diekspos luas oleh berbagai media cetak maupun elektronik dalam mempromosikan iklan hijab yang memberikan fantasi, ilusi, kesenangan, kegairahan, prestise, hasrat, seksualitas dan ekstasi bagi pemakai dan yang melihatnya. Sistem tanda dalam kapitalisme ini yang menjadi lawan dari komunitas hijabers solo yang menyebarluaskan cara memakai hijab sesuai dengan tuntunan agama.

Perjuangan kebudayaan ini bagi komunitas hijabers solo merupakan perjuangan memperebutkan makna dalam memandang simbol hijab kepada seorang perempuan muslimah. Perjuangan ini sebagai upaya mengkontruksi trend hijab di kota surakarta pada khususnya dan Indonesia pada umumnya. Para penggiat komunitas hijabers solo tidak mau para perempuan muslimah menjadi objek seksual, hasrat dan diri.

Pencapaian perlawanan komunitas hijabers solo adalah menghilangkan konstuksi sosial perbedaan makna, dalam artian jika perempuan muslimah memakai jilbab dengan sesuai tuntunan agama, tidak membeli jilbab yang tidak menutup dada, dan tidak terpikat dengan mengikuti trend jilboob maka perempuan tidak akan menjadi objek seksual, hasrat, dan diri.

Oleh karena itu, di dalam perkumpulan hijabers solo selai sebagai ajang silaturahim antar muslimah di surakarta juga ada sharing tentang pengetahuan agama dan tata cara menggunakan hijab yang baik dan bernar sesuai tuntunan agama Islam.

\section{E. SIMPULAN}

Keberadaan Komunitas Solo Hijabers merupakan sebuah fenomena gerakan sosial baru di mana kehadirannya membawa dampak tertentu bagi sebagian kalangan di masyarakat di Indonesia khususnya para muslimah atau kaum perempuan beragama 
Islam yang tergabung di dalamnya. Kemunculan Komunitas Solo Hijabers tidak serta merta tanpa tujuan, mereka hadir untuk mewadahi dan memfasilitasi para kaum muslimah yang ingin belajar untuk berbusana sesuai dengan tuntutan agama Islam yaitu dengan kewajiban mengenakan hijab bagi wanita muslim. Tujuan utamanya adalah untuk berbagi wawasan terkait fungsi dan keutamaan penggunaan hijab bagi kaum perempuan muslim.

Perjuangan kebudayaan ini bagi komunitas hijabers solo merupakan perjuangan memperebutkan makna dalam memandang simbol hijab kepada seorang perempuan muslimah. Perjuangan ini sebagai upaya mengkontruksi trend hijab di kota surakarta pada khususnya dan Indonesia pada umumnya. Para penggiat komunitas hijabers solo tidak mau para perempuan muslimah menjadi objek seksual, hasrat, dan diri karena tidak menggunakan hijab yang sesuai dengan tuntunan agama.

Selain itu, ada banyak kegiatan yang dirancang dan dilaksanakan oleh Komunitas Solo Hijabers yang memiliki manfaat yang mampu dirasakan bagi anggotanya secara khusus dan bagi khalayak umum secara keseluruhan, serta sebagai penanda bahwa Komunitas Solo Hijabers adalah juga bagian dari masyarakat. Di balik setiap agenda kegiatan yang dilakukan dalam komunitas tersebut memiliki tujuan agar diakui eksistensinya dan diterima oleh seluruh masyarakat, selain itu juga untuk menyebarkan manfaat positif bagi seluruh umat muslim sebagai bagian dari masyarakat. 


\section{DAFTAR REFERENSI}

Arikunto, Suharsimi. (2006). Prosedur Penelitian: Suatu Pendekatan Praktik. Jakarta: Rineka Cipta.

Baron, R. A., \& Donn, B. (1991). Social Psychology: Understanding Human Intraction. Needham Height: Simon \& Suster Inc.

Fealy. 2006. "Voices of Islam in Southeast Asia" : 326.

Hogg, M. A., \& Abrams, D. (1990). Social Identity Theory: Constructive and Critical Advances. New York: Springer-Verlag.

Iskandar. (2009). Metodologi Penelitian Kualitatif. Jakarta: Gaung Persada (GP Press).

Masitoh, N. dan Yuliawati, F. 2016. Gerakan dan Representasi Politik Perempuan di Kota Tasikmalaya. Jurnal Palastren, vol. 9, no. 1, hlm. 215-232.

Moleong, L. J. (2000). Metode Penelitian Kualitatif. Bandung: Rosda Karya. . (2007). Metodologi Penelitian Kualitatif. Bandung: PT Remaja Rosda Karya.

Mustafa, Kamal. 2000. "Gerakan Wanita Islam 1980-an di Indonesia”.

Poerwandari, E. K. (2007). Pendekatan Kualitatif dalam Penelitian Perilaku Manusia. Jakarta: Lembaga Pengembangan Sarana Pengukuran dan Pendidikan Psikologi (LPSP3) Fakultas Psikologi Universitas Indonesia.

Roviana, Sri. 2014. Gerakan Nahdlatul Ulama dalam Transformasi Pendidikan Politik. Jurnal Pendidikan Islam, vol. III, no. 2, hlm. 403-424.

Salim, Agus. 2006. Teori dan Paradigma Penelitian Sosial. Yogyakarta: Tiara Wacana.

Singh, Rajendra. 2010. “Gerakan Sosial Baru- Rajendra Singh”. Yogyakarta: Resist Book.

Suharko. 2006. "Gerakan Sosial: Konsep, Strategi, Aktor, Hambatan dan Tantangan Gerakan Sosial di Indonesia”. Malang: Averroes Press.

Suhendra, A. 2013. Kontestasi Identitas Melalui Pergeseran Interpretasi Hijab dan Jilbab dalam Al-Qur'an. Jurnal Palastren, vol. 6, no. 1, hlm. 1-22.

Tong, R.P. 1998. Feminist Thought Pengantar Paling Komprehensif Kepada Arus Utama Pemikiran Feminis. Yogyakarta: Jalasutra.

Walgito, B. (2002). Pengantar Psikologi Umum. Yogyakarta: Adi.

Wenger, E., Richard, M., \& Snyder, W. M. (2002). Cultivating Communities of Practice. Hardvard Business Press, Ed. 1. ISBN 978-1-57851-330-7.

Yin, R. K. (2015). Studi Kasus - Desain \& Metode. Jakarta: Rajawali Pers. 